\title{
ろいしんノ糖質代謝二交ボス影響
}

阙山大學醫學部生化學敎室（主任 清水教授）

助手仁科桂一

\section{STUDIES ON THE INFLUENCE OF L-LEUCIN UPON THE CARBOHYDRATE METABOLISM.}

By

\author{
Keiichi NISHINA \\ (From the Department of Biological Chemistry, School of Medicine, \\ University of Okayama; Director: T. Shimizu)
}

There are many investigations about the influence of leucin on fhe mechanism of sugar metabolism, it is recognized that the ingestion of leucin produces slight hyperglycemia.

But it is not certain, whether this hyperglycemia is due to the disturbance of internal secretion or to the abnormal nucleoprotein metablism, because the increase of nucleoprotein metabolism by leucin brings about hyperglycemia.

In this meaning this experiments were excued and found, that leucin ingestion brings about not only hyperglycemia in hunger but also inceases alimental and adrenalin hyperglycemia.

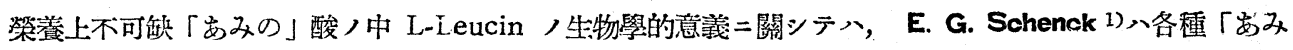
の」酸ノ血糖調節作用 7 調查シテ Leucin ハワジカニ過血糖作用 アアラワスガ, 反之Glykokoll 八血糖降下

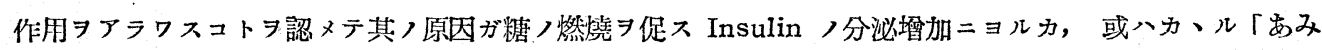

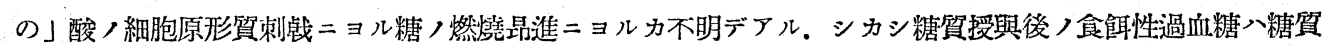
卜共=Glykokoll ヨ同時二附加スル下糖質ニョツテ起ル過血糖ガ消失スルカラ Glykokoll ハInsulin ノ分 泌ヨ促シ之ト合加作用ヨイトナムカラダト說明シテイル。 反之 Leucin ノ過血䌅作用二關シテハソノ原因 ガ不明ノマ、ニナッテイル。

H. Jensen, O. Wintersteiner \& V. d. Vigneaud 2)、 Leucin, ガ Insulin ノ一成分デアルュトラ登明

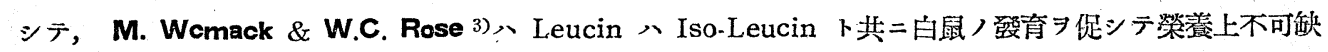

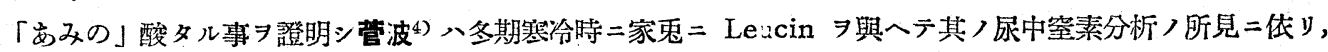

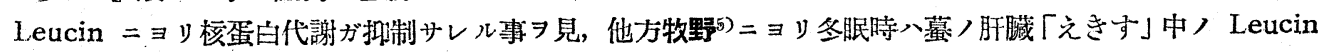
ガ夏季。）場合二比シ著シク多イコトガ認メラレテイル。核蛋白代謝ノ艺進スナハチ體內 Nucleoside Nucleic acid 等ノ增加力低血糖

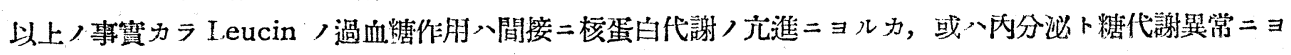
ルカ不明デアル。カ、ル意味デ Leucin，糖貿代謝二及ボス影響フ實驗シタ所以デアル。

\section{實 驗 ノ 部}

材料入精製セル L-Leucin $ᄏ$ 用七, 正常健康雄性家鬼 間絕食サシタノチ L-Leucin 7 體重 $1 \mathrm{~kg}$ 二就キ0.1g ア一定量ノ水ニトカシテ耳清脈二注射シ時間的二空腹 


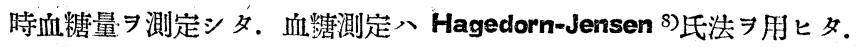

第一群家乘入對照トシテ空腹時ノ血楉量シ測定シタ。此際䐝驗操作ノ血糖量二及ブ影響シサケルタメ望驗 2 時間前家躳 軸〉血糖量

第二洋二八 L-Leucin $1: 2 \%$ 水溶液 7 正常健康雄性家束二體重 $1 \mathrm{~kg}=ッ \neq 5.0 \mathrm{cc}$ ( $0.1 \mathrm{~g}$ Leucin) 耳静脈

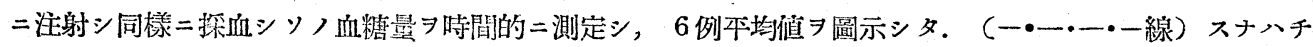

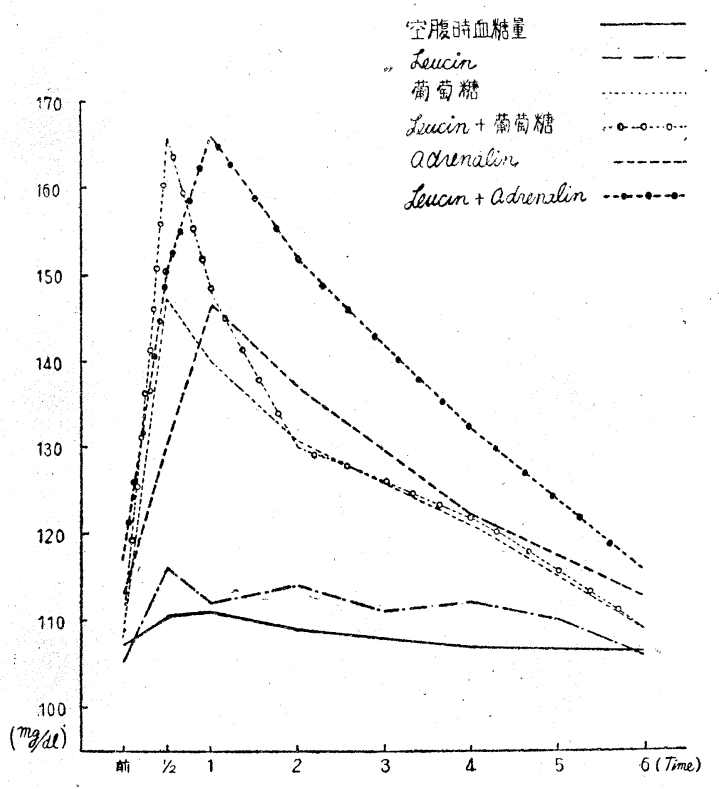

Leucin 注射後30分デ最大平均 $10.16 \%$ 血 糖增加シ示シタ二過ギナイ。

第三群二ハ20\%葡萄膅水溶液引體重 每瓦 $1.0 \mathrm{cc}$ 耳静胍二注射シ同ジク時間的二探血， y ノ血糖量 7 測定シ 6 例本均值 $ᄏ$ ………....線デ 示シタ．スナハチ糖注射後 30 分デ最大 $34.5 \%$ 八食慨性過血糖ヨ示シタ.

第四群 >正常健康雄性家鬼二八20\%葡萄糖 溶液體重 1 再 $1.0 \mathrm{cc}$ 同時 $=2 \%$ L-Leucin

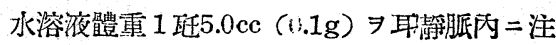
大シ同樣時間的二血䌅量 7 測定シ 6 例本均値

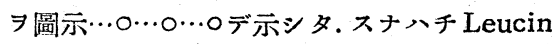
卜共二葡萄糖 血糖量增加 7 示シ,食慨性過血糖八L-Leucin ニョリ著シク習强サレル。

第五群 >正常健康雄性家鬼二八, 鹽化 Adrenalin 千倍溶液 體重 1 㝚 $0.05 \mathrm{cc}$ 皮下= 注射シ同樣時間的二血糖量 $\exists$ 測定シ 7 例平均

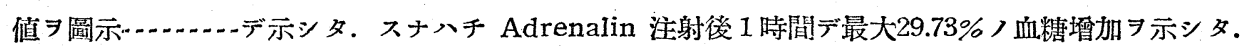

第六群ノ正常健康雄性家鬼二八鹽化A-drenalin 千倍溶液體重 1 画 $0.05 \mathrm{cc}$ 卜 $2 \%$ L-Leucin 水溶液體重 1

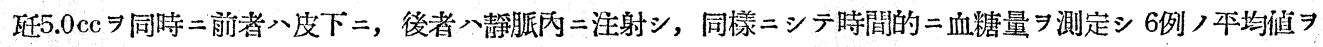

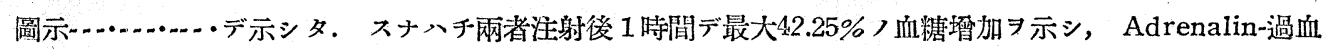
糖モ亦 Leucin ニョリ著シク增强サレルコトガ分ツタ.

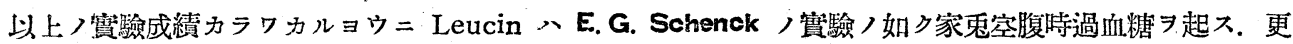

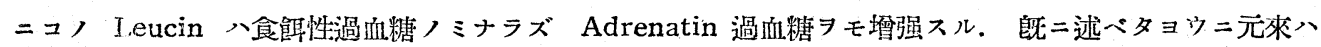

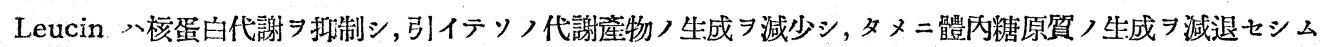
ルコトハ考へラルガ Adrenalin 過血糖入交感种經刺擊ニョル糖原質ノ分解促進ニョルコト入兓定ノ事質デ アルシ，本實驗デ Leucin ガ Adrenalin 過血糖 増强スルコトカラ Leucin 過血糖ノ作用本態入核酸代

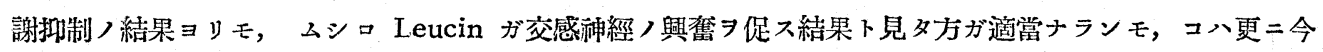
後つ哳究二侯タネバナラナイ。

\section{結論}

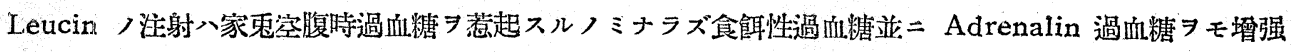
$\pi \pi$.

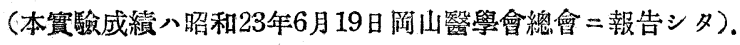


文

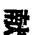

1) E.G. Schenck: Archiv für exp. Path. u. Pharmakologie. 167, 201 (1932). 2) H. Jensen, 0. Wintersteinerand V. d. Vigneaud: J. Pharmacol, and exp. Therp. 32, 387 (1928). 3 3) M. Womack and W.C. Rose: J. Biol. Chem. 116, 381 (1936). $\quad$ 4) 营波孝雄：未發表 (1944). 5)

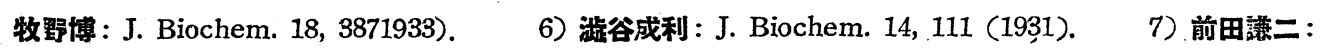
J. Biochem.'28, 85 (1938). $\quad$ 8) H. C. Hagedorn u. B. N. Jensen: Biochem Zs. 135, 46 (1923). 